\title{
Analisis Kemampuan Literasi Digital Pembelajaran Biologi di MAN Grobogan Masa Pandemi Covid 19
}

\section{Analysis Of Digital Literacy Skills in Biology Learning for Islamic Senior High School in Grobogan The Covid 19 Pandemi}

\author{
Ulfatun Muyasaroh $^{\left.1^{*}\right)}$, Listyono $^{1)}$, Ndzani Latifatur Rofi'ah ${ }^{1)}$ \\ ${ }^{1)}$ Pendidikan Biologi, Universitas Islam Negeri Walisongo Semarang, Negara Indonesia \\ *)ulfatunmuyasaroh07@gmail.com
}

diterima : 30 April 2021; dipublikasi : 30 Oktober 2021

DOI: $10.32528 /$ bioma.v6i2.5880

\begin{abstract}
ABSTRAK
Covid-19 berpengaruh terhadap pendidikan. Hal ini menyebabkan pelaksanaan pembelajaran beralih menjadi secara daring. Siswa dalam pembelajaran daring mencari referensi dari berbagai sumber, salah satunya dari internet. Siswa harus terbiasa dalam mencari, membaca, serta memahami sumber referensi dalam bentuk digital. Penelitian ini bertujuan menganalisis kemampuan literasi digital siswa pada pembelajaran daring. Penelitian ini merupakan kuantitatif deskriptif dengan menggunakan metode survei. Instrumen yang digunakan berbentuk angket skala likert yang disebar melalui google form. Pengambilan sampel menggunakan teknik simple random sampling. Teknik analisis data penelitian menggunakan statistik deskriptif. Hasil penelitian menunjukkan kemampuan literasi digital terdapat empat indikator, yaitu pencarian internet $(74,92 \%)$, pandu arah hypertext $(72,63 \%)$, evaluasi konten informasi $(77,47 \%)$, dan penyusunan pengetahuan $(76,78 \%)$. Tingkat kemampuan literasi digital siswa pada pembelajaran daring dikategorikan tinggi.
\end{abstract}

Kata kunci: Literasi Digital, Pembelajaran Biologi, Pembelajaran Daring

\begin{abstract}
Covid-19 has an impact on education. This causes face-to-face learning to switch to online learning. Students in online learning look for references from various sources, one of which is the internet. Students must be familiar with finding, reading, and understanding reference sources in digital form. This study aims to analyze students' digital literacy skills in online learning. This type of research is quantitative descriptive with survey method. The data collection instrument is in the form of a Likert scale questionnaire distributed via google form. The sampling technique used is simple random sampling. The research data analysis technique used descriptive statistics. The results showed that there are four indicators of digital literacy ability, namely internet search $(74.92 \%)$, hypertext guide $(72.63 \%)$, evaluation of information content (77.47\%), and knowledge compilation (76.78\%). The level of digital literacy skills of students in online learning is categorized as high.
\end{abstract}

Keywords: Digital Literacy, Biology Learning, Online Learning. 


\section{PENDAHULUAN}

Wabah virus Corona atau Covid 19, pertama kali muncul di Negara China, terutama di Wuhan dan menyebar ke seluruh negara di dunia (Rahmasari et al., 2020). Kasus penyebaran Covid-19 semakin cepat dan meluas, hingga jumlah lonjakan kasusnya tidak bisa diduga. Di Indonesia pandemi Covid-19 sudah berjalan satu tahun dan kasus positif semakin bertambah. Berdasarkan data Komite Penanganan Covid-19 dan Pemulihan Ekonomi Nasional (KPCPEN) pada 18 Maret 2021 penambahan kasus positif Covid-19 mencapai 1.443.853 orang (KPCPEN, 2021).

Pandemi Covid-19 mengakibatkan perubahan di negara Indonesia salah satunya yaitu aspek pendidikan (Kusuma et al., 2020). Surat Edaran Nomor 4 Tahun 2020 tentang Pelaksanaan Kebijakan Pendidikan Dalam Masa Darurat Penyebaran Coronavirus Disease (COVID-19) yang dikeluarkan oleh Menteri Pendidikan dan Kebudayaan Republik Indonesia, menjelaskan bahwa pembelajaran dilaksanakan secara daring (Mendikbud RI, 2020). Menurut Marfu'ah (2020) siswa dalam pembelajaran daring adalah mereka yang membutuhkan materi dan model pembelajaran online, misalnya diskusi secara online dengan guru dan teman, bahan ajar yang dikirimkan guru melalui platform pembelajaran daring, konsultasi, penugasan, serta ujian dilaksanakan secara daring.

Perkembangan teknologi yang pesat membuat siswa dapat memanfaatkan teknologi untuk pembelajaran daring. Sistem digital daring membuat siswa mudah dalam mencari informasi materi pembelajaran dengan bantuan internet karena tidak dibatasi ruang dan waktu (Hanik, 2020). Berdasarkan hasil Program for International Student Assement (PISA) tahun 2015, di Indonesia tingkat membaca/literasi berada di tingkat rendah mengenai dengan skor rata-rata 397. Menurut Pratama dan Hartini (2019) salah satu upaya gerakan literasi digital bisa dilakukan oleh siswa dengan membiasakan melakukan kegiatan literasi digital.

Masa pandemi Covid-19 siswa tidak hanya membutuhkan materi dari media cetak seperti LKS, buku paket, dan lainnya. Siswa lebih banyak menggunakan internet untuk mengakses informasi tentang materi yang diajarkan oleh guru saat pembelajaran daring. Informasi yang disajikan di internet dalam format digital, seperti situs web, blog, atau mailing list (Muna, 2020). Kemudahan mengakses sumber referensi dalam bentuk digital memudahkan siswa dalam belajar, tetapi dalam mengakses informasi harus 
diperhatikan karena banyak informasi yang tidak bisa dipertangungjawabkan kebenarannya tanpa mencantumkan sumber informasi yang jelas. Literasi digital menjadi suatu hal yang penting dikarenakan kemudahannya dalam mengakses internet (Hidayat et al., 2020).

Berdasarkan wawancara salah satu guru biologi di MAN 1 Grobogan dan MAN 2 Grobogan, diperoleh hasil bahwa proses pembelajaran daring menggunakan $e$ learning dari sekolah dan WhatsappGroup untuk memantau siswa yang belum absen, mengirim materi jika e-learning terdapat kendala dan siswa yang terlambat dalam pengumpulan tugas. Metode yang digunakan oleh guru yaitu mengirim materi berbentuk ppt, word, dan $p d f$ yang nantinya akan dipelajari oleh siswa di rumah, serta sumber referensi yang digunakan oleh siswa kebanyakan dari internet, tetapi beberapa siswa terlebih dahulu menanyakan kepada guru mengenai sumber tersebut valid atau tidak. Berdasarkan uraian tersebut, penelitian dengan judul "Analisis Kemampuan Literasi Digital Pembelajaran Biologi di MAN Grobogan Masa Pandemi Covid 19" perlu dilakukan.

\section{METODE}

Penelitian ini menggunakan jenis penelitian kuantitatif deskriptif dengan menggunakan metode survey. Penelitian deskriptif untuk mengetahui nilai-nilai dari satu variabel atau lebih (independent) serta tidak membandingkan atau menghubungkan dengan variabel lainnya (Khoiri, 2018, p. 6). Data kuantitatif diperoleh dari analisis skor pada jawaban subjek terhadap angket mengenai literasi digital siswa. Penelitian ini dilakukan di MAN 1 Grobogan dan MAN 2 Grobogan pada bulan April di semester genap tahun 2021/2022. Populasi penelitian ini adalah peserta didik kelas X dan XI di MAN 1 dan MAN 2 Grobogan. Penelitian ini menggunakan teknik pengambilan sampel jenis simple random sampling dan pengumpulan data berupa angket literasi digital dengan skala likert 1-5 yang dibagikan kepada siswa melalui google form. Indikator serta daftar pernyataan kuesioner mengenai kemampuan literasi digital siswa diadaptasi dari penelitian yang dilakukan oleh Zaenudin et al (2020). 
Tabel 1. Kisi-Kisi Instrumen Kemampuan Literasi Digital Siswa

\begin{tabular}{cllcc}
\hline No & Variabel & \multicolumn{1}{c}{ Indikator } & \multicolumn{2}{c}{ Nomor Item } \\
\cline { 3 - 4 } & & Positif & Negatif \\
\hline \multirow{2}{*}{$\begin{array}{l}\text { Literasi } \\
\text { Digital }\end{array}$} & Pencarian internet & $1,2,3$ & 4 \\
\cline { 2 - 4 } & Pandu arah hypertext & $5,6,8$ & 7 \\
\cline { 2 - 4 } & Evaluasi konten informasi & $9,10,12$ & 11 \\
\cline { 2 - 4 } & Penyusunan pengetahuan & $13,15,16$ & 14 \\
\hline
\end{tabular}

Analisis data menggunakan statistik deskriptif, data yang digunakan berdasarkan skor jawaban siswa dari angket kemampuan literasi digital siswa yang diberikan. Data kuantitatif dari angket dianalisis dalam bentuk persentase.

Nilai persentase hasil penskoran siswa $(\mathrm{X})$ dengan menggunakan rumus :

$$
X=\frac{\Sigma \times i}{s} \times 100 \%
$$

Keterangan :

$\sum x \mathrm{i} \quad=$ jumlah skor yang diperoleh

$\mathrm{S} \quad=$ total skor seluruhnya

Tabel 2. Intrepretasi Skor

\begin{tabular}{ccc}
\hline No & $\begin{array}{c}\text { Interval Persentase } \\
\text { Skor }\end{array}$ & Kriteria \\
& $85 \leq \%$ skor $\leq 100$ & Sangat Tinggi \\
\hline 1. & $69 \leq \%$ skor $\leq 84$ & Tinggi \\
\hline 2. & Sedang \\
\hline 3. & $53 \leq \%$ skor $\leq 68$ & Rendah \\
\hline 4. & $37 \leq \%$ skor $\leq 52$ & Sangat Rendah \\
\hline 5. & $20 \leq \%$ skor $\leq 36$ & \\
\hline
\end{tabular}

(Sumber: Setyosari, 2016, p. 234) 


\section{HASIL DAN PEMBAHASAN}

Penelitian "Analisis Kemampuan Literasi Digital Pembelajaran Biologi di MAN Grobogan Masa Pandemi Covid 19” ini dilakukan selama satu minggu, mulai tanggal 19-24 April 2021. Subjek penelitian ini adalah siswa-siswi kelas X dan XI MIPA, setiap jenjang diambil dua kelas dengan jumlah seluruh responden pada sebanyak 241 siswa.

Tabel 3. Data Distribusi Persentase Tingkat Kemampuan Literasi Digital Siswa

\begin{tabular}{llcc}
\hline $\begin{array}{c}\text { Interval } \\
\text { Persentase Skor }\end{array}$ & \multicolumn{1}{c}{ Kriteria } & Frekuensi & Persentase \\
\hline $85 \leq \%$ skor $\leq 100$ & Sangat Tinggi & 33 & $13,69 \%$ \\
\hline $69 \leq \%$ skor $\leq 84$ & Tinggi & 167 & $69,29 \%$ \\
\hline $53 \leq \%$ skor $\leq 68$ & Sedang & 39 & $16,18 \%$ \\
\hline $37 \leq \%$ skor $\leq 52$ & Rendah & 1 & $0,41 \%$ \\
\hline $20 \leq \%$ skor $\leq 36$ & Sangat Rendah & 1 & $0,41 \%$ \\
\hline Jumlah & & 241 & $100 \%$ \\
\hline
\end{tabular}

Hasil penelitian menunjukkan bahwa dari 241 siswa terdapat 33 siswa $(13,69$ \%) memiliki tingkat kemampuan literasi digital sangat tinggi, 167 siswa $(69,29 \%)$ memiliki tingkat kemampuan literasi digital tinggi, 39 siswa (16,18\%) memiliki tingkat kemampuan literasi digital sedang, 1 siswa $(0,41 \%)$ memiliki tingkat kemampuan literasi digital rendah, dan 1 siswa $(0,41 \%)$ memiliki tingkat kemampuan literasi digital sangat rendah. Hal ini dapat dilihat dari beberapa indikator seperti pencarian internet, pandu arah hypertext, evaluasi konten informasi, penyusunan pengetahuan. Indikator mengenai kemampuan literasi digital siswa di MAN se-Grobogan dapat dilihat melalui perhitungan analisis persentase jawaban indikator pada Tabel 4.

Tabel 4. Data Rata-Rata Persentase Jawaban Indikator 


\begin{tabular}{clcc}
\hline No & \multicolumn{1}{c}{ Indikator } & $\begin{array}{c}\text { Persentase tiap } \\
\text { Indikator }\end{array}$ & Kategori \\
\hline 1. & Pencarian internet & $74,92 \%$ & Tinggi \\
\hline 2. & Pandu arah hypertext & $72,63 \%$ & Tinggi \\
\hline 3. & Evaluasi konten informasi & $77,47 \%$ & Tinggi \\
\hline 4. & Penyusunan pengetahuan & $76,78 \%$ & Tinggi \\
\hline & Rata-rata keseluruhan & $75,45 \%$ & Tinggi \\
\hline
\end{tabular}

Indikator pencarian internet diperoleh hasil sebesar 74,92 \%, hal ini menunjukkan bahwa indikator pencarian internet berada pada kategori tinggi. Siswa selama pembelajaran daring lebih senang mencari materi biologi di internet daripada buku, pencarian informasi yang sering dilakukan oleh siswa melalui search engine seperti yahoo, ask, google, dan sekarang menjadi kebiasan baru oleh siswa menggunakan internet untuk belajar dan mengakses informasi. Berdasarkan penelitian Muasyaroh dan Lucia (2020) dapat dilihat bahwa rata-rata setiap individu memiliki kemampuan literasi digital yang cukup baik, terutama dalam mencari, memahami, dan menggunakan referensi dari internet. Hal ini akan mendukung setiap individu saat mengikuti pelaksanaan pembelajaran daring di masa pandemi Covid-19.

Indikator pandu arah hypertext, berdasarkan hasil penelitian diperoleh sebesar $72,63 \%$. Hal ini menunjukkan bahwa indikator pandu arah hypertext berada pada kategori tinggi. Siswa dapat mencari berbagai informasi melalui web browser dengan memperhatikan bandwidth, informasi yang didapatkan dari web browser memberikan hasil yang sama. Selain itu, mengenai menelusuri informasi hypertext dan hyperlink secara lebih lanjut siswa tidak tertarik. Hal ini sejalan dengan penelitian Sari (2019) tentang rendahnya pengetahuan siswa terkait hypertext dan hyperlink yang merupakan istilah baru bagi siswa walaupun telah mengakses internet dalam setiap harinya.

Indikator evaluasi konten informasi, berdasarkan hasil penelitian diperoleh hasil $77,47 \%$. Hal ini menunjukkan bahwa indikator tersebut berada pada kategori tinggi. Selama pembelajaran daring siswa sering menghabiskan waktu untuk mencari informasi di internet. Siswa menggunakan portal berita online sebagai referensi untuk mencari informasi yang ditandai dengan laman tertentu, seperti pengggunaan .com, .net, dan lainnya. Siswa memiliki kemampuan untuk memverifikasi informasi yang diterima 
dari media internet, serta melakukan konfirmasi kebenaran informasi dengan teman, orang tua dan guru untuk menghindari informasi hoax. Konfirmasi dalam literasi digital sangat penting untuk memperkuat kemampuan mencari dan menyebarkan informasi secara bertanggung jawab. Menurut Novanda (2019) informasi kegiatan akademik yang didapatkan di media digital terlebih dahulu harus dipastikan keakuratannya.

Indikator terakhir yaitu penyusunan pengetahuan, berdasarkan hasil penelitian diperoleh hasil $76.78 \%$. Hal ini menunjukkan bahwa indikator tersebut berada pada kategori tinggi. Siswa dalam mendapatkan informasi kebenaran selalu mencari melalui portal berita online ternama, dan beberapa siswa selalu menyertakan sumber referensi saat mengerjakan tugas. Berdasarkan penelitian Irhandayaningsih (2020) pada aspek pengguna informasi responden dapat mengutip sumber yang berkaitan dengan materi dan dapat membedakan isi dari beberapa referensi yang digunakan dalam menyusun tugas yang diikuti selama pembelajaran daring. Selain itu, siswa menyampaikan informasi menggunakan kalimat yang mudah dimengerti serta melampirkan gambar atau video yang relevan kepada semua orang, sehingga informasi tersebut dapat dipahami dan dipercaya. Hal ini menunjukkan bahwa, selain menggunakan unsur teks siswa menyampaikan informasi disertai gambar atau video yang sesuai.

Berdasarkan uraian hasil analisis persentase setiap indikator literasi digital siswa dengan jumlah enam belas pernyataan rata-rata persentase keseluruhan indikator sebesar 75,45 \%. Hal ini menunjukkan bahwa indikator literasi digital siswa berada pada kategori tinggi, sehingga mengakibatkan tingkat kemampuan literasi digital siswa selama pembelajaran daring dikategorikan tinggi.

Literasi digital siswa terdapat empat indikator, dari keempat indikator hasil rata-rata paling tinggi adalah indikator evaluasi konten informasi diperoleh hasil sebesar 77,47 \% dan indikator dengan hasil rata-rata paling rendah adalah indikator pandu arah hypertext diperoleh hasil sebesar 72,63\%. Hal ini sejalan dengan penelitian Novanda (2019) mengevaluasi informasi yang berhubungan dengan kegiatan akademik yang di dapatkan setiap individu di media digital harus dipastikan terlebih dahulu keakuratannya. Salah satu kegiatan pencarian literatur ilmiah adalah banyaknya situs yang memberikan informasi melalui blogspot, google book, open jurnal system, dan lain-lain Contohnya blogspot yang banyak digunakan karena alasan kemudahan akses 
penelusuran serta menyajikan informasi yang bermacam-macam meskipun secara ilmiah dalam kredibilitasnya masih kurang dibandingkan dari situs lainnya.

Indikator pandu arah hypertext menghasilkan hasil persentase rata-rata rendah dibanding dengan indikator yang lainnya karena siswa tidak tertarik menelusuri informasi mengenai istilah baru bagi mereka yaitu hypertext dan hyperlink. Menurut Izza dan Munawir (2021) pada proses pembelajaran daring hypertext dapat memudahkan siswa yang tertinggal dalam mengikuti pembelajaran dengan membuka kembali materi yang telah jelaskan guru. Hypertext sangat membantu dalam pembelajaran daring karena dapat dibaca setiap saat dan dimulai dari semua bagian.

Pembelajaran daring dapat meningkatkan kemampuan literasi digital siswa yang dapat dilihat dari pencarian internet, pandu arah hypertext, evaluasi konten informasi, dan penyusunan pengetahuan. Menurut Tang dan Chaw (2016) setiap individu harus memiliki literasi digital atau keterampilan prasyarat untuk bisa belajar secara efektif dalam mengikuti pembelajaran secara daring karena selama pembelajaran daring siswa mendapatkan materi dan instruksi secara tidak langsung oleh guru melalui perangkat teknologi. Menurut Yasid (2020) literasi digital perlu terintegrasi pada sistem pembelajaran di masa pandemi, sehingga siswa dalam memaknai karakter literasi digital bisa menjadi pribadi yang cerdas, tangguh, serta bijak.

\section{KESIMPULAN DAN SARAN}

Tingkat kemandirian belajar pada pembelajaran biologi siswa MAN di Kabupaten Grobogan pada masa pandemi menunjukkan bahwa tingkat kemandirian belajar siswa berada pada kategori tinggi dengan enam indikator, yaitu tujuan belajar $(74,48 \%)$, strategi belajar $(75,62 \%)$, manajemen waktu $(79,34 \%)$, lingkungan $(84,43$ $\%)$, pencarian bantuan $(77,34 \%)$, dan evaluasi diri $(74,85 \%)$. Saran dalam penelitian ini adalah siswa banyak mengakses informasi di internet mengenai materi pelajaran yang belum dipahami, tetapi siswa harus memperhatikan sumbernya karena tidak semua sumber referensi dapat dipertanggungjawabkan. Selain itu, guru juga perlu memberikan feedback terhadap tugas yang dikerjakan oleh siswa dengan mengonfirmasi terkait sumber referensi yang digunakan siswa sudah sesuai atau belum, sehingga siswa tahu yang benar dan yang kurang tepat. 


\section{DAFTAR PUSTAKA}

Hanik, E. U. (2020). Self Directed Learning Berbasis Literasi Digital pada Masa Pandemi Covid-19 di Madrasah Ibtidaiyah. Jurnal IAIN Kudus 8, 183-208.

Hidayat, D. R., Rohaya, A., Nadine, F., Ramadhan, H., \& Rawamangun. (2020). Kemandirian Belajar Siswa dalam Pembelajaran Daring pada Masa Pandemi Covid -19. Perspektif Ilmu Pendidikan 34(2), 147-154.

Irhandayaningsih, A. (2020). Pengukuran Literasi Digital pada Peserta Pembelajaran Daring di Masa Pandemi COVID-19. Jurnal Undip 4(2), 231-240.

Izza, A. dan Munawir. (2021). Hypertext Based Interactive Media Analysis In Growing Student Reading Interest Through Online Learning. Pendidikan Teknologi Informasi 5(1), 69-80.

Khoiri, Nur. (2018). Metodologi Penelitian Pendidikan (Ragam, Model, \& Pendekatan). Semarang.Southeast Asian Publishing.

KPCPEN. (2021). Update Data Kasus Covid19. https://covid19.go.id/. 18 Maret 2020 (11.43).

Kusuma, R. F., Sari, Y., \& Khoirotun, N. (2020). Menumbuhkan Kemandirian Siswa Selama Pembelajaran Daring sebagai Dampak Covid-19 di SD. Jurnal Riset Pendidikan Dasar, 7-13.

Marfu'ah, S. (2020). Analisis Kemandirian Belajar Siswa dalam Pembelajaran Matematika Secara Online di SMP Negeri 1 Cilongok. Skripsi. Institut Agama Islam Negeri Purwokerto.

Mendikbud RI. (2020). Surat Edaran Nomor 4 Tahun 2020 Tentang Pelaksanaan Kebijakan Pendidikan dalam Masa Darurat Penyebaran Coronavirus Disease (COVID-19).

Muasyaroh, Husnul dan Lucia, Riyanto. (2020). Peran Literasi Digital dan Task Value Terhadap Self-Regulated Learning Mahasiswa. Psikologi Ulayat 10(10), 20.

Muna, F. N. (2020). Pengaruh Penerapan Literasi Digital dan Kemandirian Belajar Terhadap Prestasi Belajar IPA pada Masa Pandemi Covid-19 Siswa Kelas IX SMP NU Suruh Tahun Pelajaran 2020/2021. Skripsi. Institut Agama Islam Negeri Salatiga.

Novanda, R.R. (2019). Hubungan Literasi Digital dengan Self Directed Learning pada Mahasiswa di Daerah Miskin Sumatera. Ilmu Informasi 21(1), 20-24. 
Pratama, W. A., \& Hartini, S. (2019). Analisis Literasi Digital Siswa Melalui Penerapan E-Learning Berbasis Schoology. Innovation and Physics Teaching 06(1), 9-13.

Rahmasari, A. F., Setiawan, F., \& Nanda, M. (2020). Pengaruh Pembelajaran Online Terhadap Kemandirian Belajar Siswa Kelas II SD Muhammadiyah 17 Surabaya di Tengah Pandemi Covid-19. Jurnal Pendidikan Guru Sekolah Dasar 04(2), $158-168$.

Sari, S.S. (2019). Kemampuan Literasi Digital Kalangan Siswa SMP dan SMA di Daerah Pedesaan Kabupaten Blitar. Thesis. Universitas Airlangga.

Setyosari, P. (2016). Metode Penelitian Pendidikan dan Pengembangan. Jakarta.Prenada Media.

Tang, C. M., dan Chaw, L. Y. (2016). Digital Literacy: A Prerequisite for Effective Learning In a Bleanded Environment. Electronic Journal of e-Learning 14(1), 54-65.

Yasid, A. (2020). Strategi Pembelajaran Berbasis Karakter Literasi Digital Menghadapi Pandemi Covid-19. Diskusi Daring Tematik Nasional, 52-56.

Zaenudin, H. N., Fahrul, A, Affandi, M. Priandono, T.E Endriski, M., \& Haryanegara, A. (2020). Tingkat Literasi Digital Siswa Smp Di Kota Sukabumi Digital Literacy Level Of Sukabumi City' S Junior High. Penelitian Komunikasi 23(2), $167-180$. 